\title{
PERAN RADIOGRAFER DALAM PEMERIKSAAN ULTRASONOGRAFI (USG)
}

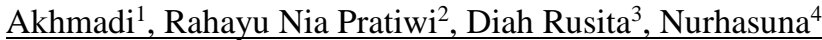 \\ ${ }^{1}$ Department of Radiology, Tirta Medical Center Jakarta, Indonesia \\ ${ }^{2}$ Department of Radiodiagnostic and Radiotheray Techniques, Poltekkes Kemenkes Jakarta 2 \\ ${ }^{3,4}$ Poltekkes Kemenkes Semarang
}

Corresponding author: akhmadi.usg@gmail.com

\begin{abstract}
Background: USG is one of the many areas of specialization for radiographers in Indonesia to develop their professional careers. Many countries in the world have implemented an ultrasound education system as an alternative field in the career development of health workers, in order to support the improvement of health facility services for the community. Especially in the Southeast Asia region, there has been special ultrasound education, namely in Malaysia, Singapore, and Thailand. In Indonesia, the USG education program has been specifically included in the radiographer education curriculum system, so that ultrasound is one part of the competence possessed by radiographers.

Methods: This study uses a library research method or literature review, and a qualitative descriptive approach, through interviews, regarding the role of the radiographer in USG

Results: Of the 3 (three) journals, literature reviews were conducted, sourced from Europe, especially England, and interviews were conducted with the researchers, then continued with 1 (one) interview from the United States sonographer, and 1 (one) interview from the Australian Sonologist. All of them explain the active role of the radiographer on ultrasound.

Conclusions: Radiographers can play an active role in ultrasound services, especially in the field of ultrasound examination techniques, which will then produce a report in the form of an ultrasound image, and the results of an interim report, which will then be concluded by the doctor, in this particular case by the Radiology Specialist
\end{abstract}

Keyword: USG, Radiografer, Sonografer

\section{Pendahuluan}

USG atau pencitraan gelombang suara ultrasonik adalah modalitas pencitraa medis yang memanfaatkan gelombang suara berfrekuensi ultrasonik untuk menampilkan gambar struktur jaringan, dan organ dalam tubuh $^{1,2}$. Menurut Berry Goldberg, seorang Radiologist dan Pionir di bidang Ultrasound, dari Thomas Jefferson University Hospital, pendidikan USG tidak hanya interpretasi hasil, tapi juga terdapat ketrampilan teknik dalam pengambilan gambar $\mathrm{USG}^{3}$.

Menurut standar profesi Radiografer terbaru, berdasarkan keputusan Mentri Kesehatan No 01/07/Menkes/316/2020, memuat cakupan kompetensi USG, khususnya diaspek ketrampilan teknik dalam pengambilan gambar, meliputi pemeriksaan USG Abdomen, Obstertic (Kehamilan), Gynecology (Kebidanan), Thyroid, Mammae,
Muskuloskeletal, Vaskuler, Echocardiografi, Pediatrik, Testis, dan Thorax ${ }^{4}$. Boleh dikatakan hampir seluruh jaringan, dan organ tubuh manusia, masuk kedalam cakupan area kompetensi Radiografer dalam bidang USG, untuk dapat dilakukan pencitraan dengan menggunakan USG.

Aspek keterampilan teknis pada bidang USG, tidak hanya semata-mata hanya melakukan pengambilan gambar, layaknya Radiografer mengerjakan pemeriksaan konvensional radiografi pada pemeriksaan thorax, melainkan memiliki tingkat kompleksitas yang cukup tinggi dan rumit, dimana Radiografer yang memiliki kompetensi USG, atau yang banyak dikenal di dunia, dengan istilah Sonografer, harus tahu dan paham sonoanatomi, intrumentasi - fisika (knobologi), variasi bentuk kelainan bawaan, artefak ultrasound, sonopatologi, dan sedikit banyak pemahaman penunjang medis lainnya, 
misalkan nilai hasil laboratorium, guna menajamkan kebutuhan jaringan atau organ apa yang di fokuskan untuk di ambil, untuk dikaji lebih dalam.

Oleh karena, sudah terdapat kompetensi di bidang USG pada standar profesi Radiografer, saya sebagai penulis mencoba mengkaji dari segi kajian literature, dan metode deskriptif kualitatif, melalui wawancara, mengenai peranan Radiografer pada pemeriksaan USG.

\section{Metode}

Jenis penelitian yang digunakan ialah penelitian kepustakaan (library research) yaitu penelitian yang menggunakan metode pengumpulan data pustaka atau penelitian yang objek penelitiannya digali melalui beragam informasi kepustakaan, dan penilitan ini juga melakukan pendekatan deskriptif kualitatif, yaitu pendekatan penelitian dengan data - data yang dikumpulkan berupa kata kata, gambar - gambar, dan bukan angka. Data tersebut diperoleh dari hasil wawancara. Fokus penelitian ini adalah peran Radiografer dalam pemeriksaan USG.

\section{Hasil dan Pembahasan}

Berdasarkan hasil penelusuran kajian literature, terdapat 3 (tiga) jurnal yang ditulis oleh Gill Harrison serorang Radiografer dan juga Sonografer dari Inggris, dimana dia dan kawan peneliti lainnya, melakukan survey di seluruh kawasan Eropa, mengenai peran Radiografer pada bidang USG, dan hasilnya mencoba menyoroti ruang lingkup praktik, dan hambatan yang dihadapi di beberapa Negara Eropa untuk memungkinkan Radiografer mengembangkan keterampilan, dan kompetensi mereka dalam bidang USG.

Terdapat 27 Negara Eropa yang berpartisipasi dalam survey tersebut, sehingga diperoleh hasil Radiografer dapat mempraktekkan USG di Negaranya sebanyak $48 \%$, dan $11 \%$ memiliki keterlibatan terbatas dalam bidang USG. Negara tanpa keterlibatan Radiografer dalam USG, dan kurangnya penerimaan dari profesi medis lainnya sebanyak $52 \%$, dan/atau terbatas pendidikan USG secara spesifik sebesar $39 \%$ sebagai faktor dominan. Oleh karena itu, Perhimpunan Radiografer pada kawasan Eropa, mendorong terciptanya ekosistem yang baik, sehingga, dapat berkembang kompetensi USG pada Radiografer, melalui pendidikan program khusus USG, penerimaan oleh profeional tenaga medis lainnya, dan perubahan perundang - undangan ${ }^{5,6,7}$.

Berdasarkan hasil korespondensi langsung, secara tertulis yang dilakukan penulis, terhadap peneliti tersebut yaitu Gill Harison, khususnya di kawasan persemakmuran Inggris, mencakup Skotlandia, dan Irlandia Utara, tidak ada aturan khusus mengenai siapa saja yang diperbolehkan melakukan pemeriksaan USG, hal ini dapat dilakukan oleh Radiografer, Bidan, Perawat, dan tentu saja oleh Dokter, baik oleh Dokter umum, maupun Dokter Spesialis. Menariknya, disana Radiografer yang memiliki kompetensi USG, atau Sonografer, dapat bertanggung jawab langsung terhadap laporan hasil akhir dari pemeriksaan USG yang dilakukan, atau dalam hal ini melakukan diagnosa.

Berdasarkan hasil korespondensi langsung, secara tertulis, terhadap seorang Sonografer di Texas, Amerika Serikat, yaitu Jane Blend, yang merupakan mantan Direktur Program USG di El Centro Collage, yang sebelumnya memiliki latar belakang pendidikan Radiografer. Di Amerika Serikat, ekosistem Radiografer yang mengembangkan spesialisasi di bidang USG, sudah sangat mendukung, baik dari segi pendidikan, penerimaan dari profesi medis lainnya, dan peraturan perundang undangan. Hal ini menjadikan sistem pendidikan Sonografer, banyak di adopsi oleh Negara lain, guna meniru sistem pendidikan dan pengembangan profesi bidang USG di Negara yang mengadopsinya, contohnya seperti Kanada, Korea Selatan, dan Indonesia.

Berdasarkan hasil korespondensi langsung, secara tertulis terhadap Sue Westerway, yaitu seorang Sonologis dari Australia, Sonologis yaitu istilah yang disematkan bagi orang yang dari latar belakang pendidikan kedokteran, mengambil pendidikan bidang USG, yang memiliki kewenangan selain bidang teknik pemeriksaan, dapat pula memiliki kewenangan intepretasi hasil pemeriksaan. Hal ini berbeda dengan kewenangan Sonografer, yang hanya terbatas pada teknis pengambilan gambar USG, dan membuat laporan tertulis, guna diajukan ke seorang Sonologis, guna dilakukan interpretasi hasil akhir, berupa diagnosa pemeriksaan USG. Di Australia, bagi Radiografer, yang ingin menjadi Sonografer, peluangnya terbuka lebar, hal ini dapat 
ditinjau, dari aspek pendidikan. penerimaan profesi medis lainnya, peraturan perundang undangan, dan sistem pembayaran jasa medis.

Khusus sistem pembayaran jasa medis yang diterima, berdasarkan wawancara penulis, terhadap Radiografer Indonesia yang telah menempuh pendidikan S2 di Australia, yaitu Putu Irma, rata-rata pendapatan per-tahun Radiografer level pemula sebesar Rp.500 Juta/thn, sedangkan untuk sonografer di level pemula sebesar 1,5 Milliyar/thn. Oleh karena, ekosistem yang baik, dilihat dari aspek pendidikan dan lapangan kerja yang banyak terserap di pelayanan kesehatan, sehingga seperti halnya, di Amerika Serikat, sistem pendidikan USG di Australia, banyak di adopsi Negara lain, seperti Selandia Baru, Malaysia, Singapura, Thailand, dan tentu saja Indonesia.

Hasil dari survey yang dilakukan di Eropa terhadap peran Radiografer pada bidang USG, sangat menarik untuk di telaah lebih lanjut, karena tiap Negara Eropa memiliki sistem perundang - undangannya tersendiri, seperti halnya di Inggris, dimana Radiografer, yang berperan sebagai Sonografer, dapat melakukan intepretasi hasil secara independen, hal ini ternyata dikarenakan aturan hukumnya memungkinkan, karena belum tertulis secara jelas, dan di Inggris, memiliki keterbatasan Dokter spesialis Radiologi, hal ini yang memungkinkan hal tersebut dapat terjadi.

Di Indonesia, sistem pendidikan Radiografer, secara kurikulum dan kompetensi telah memasukan bidang USG dalam cakupan area kompetensinya, namun hanya terbatas pada teknik pemeriksaan, dan pembuatan laporan dekriptif terhadap hasil pemeriksaan, yang kemudian akan di tindak lanjuti oleh hasil akhir oleh Dokter spesialis Radiologi.

Pemodelan alur kerja Sonografer di Indonesia, meniru sistem Sonografer layaknya di Negara Amerika dan Australia. Hal ini akan meminimalisir adanya resistensi oleh profesi kesehatan lainnya, terhadap peran Sonografer. Yang mana area kompetensinya, saling mendukung, tidak terlalu banyak adanya area kompetensi yang tumpang tindih. Di kedua Negara tersebut, yang telah memiliki sistem jaminan kesehatan nasional, yang menyebabkan hampir semua pelayanan di fasilitas kesehatan di tanggung oleh Negara, berdampak pada banyaknya masyarakat yang akan memeriksakan kesehatannya di pelayanan kesehatan tersebut. Oleh karena itu, kehadiran Sonografer menjadi solusi alternatife, guna mempersingkat waktu tunggu yang harus di tempuh oleh pasien, dalam menjalani pemeriksaan USG, dan akan berdampak pada pelayanan kesehatan lainnya, yang menjadi lebih efektif dan efisien.

\section{Simpulan}

Radiografer dapat berperan aktif dalam pelayanan USG, khususnya dibidang teknik pemeriksaan USG, yang selanjutnya akan menghasilkan dalam bentuk laporan gambar USG, dan hasil laporan sementara, yang kemudian akan disimpulkan oleh Dokter, yang dalam hal ini khususnya oleh Dokter Spesialis Radiologi.

\section{Daftar Pustaka}

Smith (nee Bates) J. Ultrasound Teaching Manual: The Basics of Performing and Interpreting Ultrasound Scans, 3rd edition. Ultrasound. 2013;21(4):234-234. doi: $10.1177 / 1742271 \times 13504178$

Block B. The Practice of Ultrasound. Thieme New York; 2004.

Goldberg, BB. Worldwide education: Past, present, and future, Radiology, Thomas Jefferson University Hospital, Philadelphia, PA; 2003

Keputusan Menteri Kesehatan No. 316 tahun 2020. Tentang Standar Profesi Radiografer Indonesia

Gill, Harison, et all. The role of radiographers in ultrasound: A survey of the national societies within the European Federation of Radiographer Societies (EFRS); 2020

Gill, Harison, et all. Radiographers in ultrasound: Motivation and role expansion. A survey of European Federation of Radiographer Societies (EFRS); 2021

Gill, Harison, et all. Radiographers' individual perspectives on sonography - A survey of European Federation of Radiographer Societies (EFRS); 2021 